\title{
Struktur Janturan Wayang Kulit Purwa Yogyakarta
}

\author{
Endah Budiarti
}

Jurusan Pedalangan, Fakultas Seni Pertunjukan, Institut Seni Indonesia Yogyakarta

Email: endahbudiarti30@yaho.coid

\begin{abstract}
The purpose of this study was to find the structure janturan of the Yogyakarta shadow puppet. A further goal of this research is to find a method for learning puppetry language, especially janturan language. To achieve the above objectives, the researchers will first identify and categorize the structure of janturan carried out by Ki Hadi Sugito, Ki Timbul Hadiprayitno, Ki Suparman, and Mudjanattistomo. Second, the grammatical structure of the Yogyakarta senior puppeteers' puppets was then reduced to the grammatical structure of the Yogyakarta shadow puppet show. To find the structure janturan of Yogyakarta Purwa shadow puppet, this study will apply structural analysis. The concept of tatas in chess aesthetics is the version of Soetarno et al. (2007) and the grammatical structure of the Sasangka version (1989) were used as analysis blades in this study. Janturan is the ukara-ukara ('sentences') kenès which are arranged in a complete, sequential, and not overlapping manner. As a ukara certainly has a grammatical structure. To be able to find the grammatical structure of scattering, the tatas concept and the grammatical theory of Javanese language are used. From the results of the study of the (grammatical) structure of the Yogyakarta senior mastermind's succession, the following pattern is obtained: The first part is a section that contains worship. The second part of the janturan contains the greatness of the kingdom which is the center of storytelling. The third part of janturan contains the great king in the great kingdom who is the center of storytelling. The fourth part of the janturan is about the preparation of the trial and those present at the hearing. It is expected that the results of this study can improve teaching materials in the subject of Bahasa Pedalangan, Pedalangan Rhetoric, and Basics of Pakeliran in the Pedalangan Department.
\end{abstract}

Keywords: janturan; grammatical structure; method

\begin{abstract}
Abstrak
Tujuan penelitian ini adalah menemukan struktur janturan wayang kulit purwa Yogyakarta. Tujuan lebih jauh dari penelitian ini ialah menemukan satu metode belajar bahasa pedalangan khususnya bahasa janturan. Untuk mencapai tujuan di atas, pertama-tama peneliti akan mengidentifikasi dan mengkategorikan struktur janturan yang dibawakan oleh Ki Hadi Sugito, Ki Timbul Hadiprayitno, Ki Suparman, dan Mudjanattistomo. Kedua, struktur gramatikal janturan dalang-dalang senior Yogyakarta tersebut kemudian direduksi menjadi struktur gramatikal janturan wayang kulit purwa Yogyakarta. Untuk menemukan struktur janturan wayang kulit purwa Yogyakarta penelitian ini akan menerapkan analisis struktural. Konsep tatas dalam estetika catur versi Soetarno dkk. (2007) dan struktur gramatikal ukara versi Sasangka (1989) digunakan sebagai pisau analisis dalam penelitian ini. Janturan merupakan ukara-ukara ('kalimat-kalimat') kenès yang disusun secara lengkap, urut,
\end{abstract}


dan tidak tumpang tindih. Sebagai sebuah ukara tentu memiliki struktur gramatikal. Untuk dapat menemukan struktur gramatikal janturan digunakan konsep tatas dan teori struktur gramatikal bahasa Jawa. Dari hasil pelacakan terhadap struktur (gramatikal) janturan para dalang senior Yogyakarta, diperoleh pola sebagai berikut: Bagian pertama merupakan satu bagian yang berisi tentang doa pemujaan. Bagian kedua dari janturan berisi tentang kebesaran kerajaan yang menjadi pusat penceritaan. Bagian ketiga dari janturan berisi tentang raja agung di kerajaan besar yang menjadi pusat penceritaan. Bagian keempat dari janturan berisi tentang persiapan sidang dan yang hadir di dalam sidang. Diharapkan hasil penelitian ini dapat menyempurnakan bahan ajar mata kuliah Bahasa Pedalangan, Retorika Pedalangan, dan Dasar-dasar Pakeliran di Jurusan Pedalangan.

Kata kunci: janturan; struktur gramatikal; metode

\section{Pendahuluan}

Janturan merupakan bagian dari unsur naratif pakeliran Yogyakarta. Unsur naratif pakeliran Yogyakarta terdiri atas janturan, kandha, carita dan pocapan (Mudjanattistomo, 1977: 14). Janturan adalah wacana yang diucapkan dalang berupa deskripsi suatu adegan yang sedang berlangsung, mencakup suasana tempat (negara), tokoh, dan peristiwa dengan diiringi sirepan gending (Mudjanattistomo, 1977: 14; Murtiyoso, dkk. 2007: 10). Sebagai salah satu unsur naratif pakeliran, dikatakan oleh Murtiyoso, dkk. (2007: 11) bahwa janturan memiliki fungsi dan peranan sangat penting dalam pakeliran. Lebih lanjut mereka mengatakan bahwa ditinjau dari aspek penyajiannya, janturan memiliki dua fungsi, yaitu fungsi tehnik dan fungsi estetik. Secara tehnik janturan mendeskripsikan suasana sesuatu yang belum terungkap lewat sarana ekspresi dramatik lainnya. Selain itu janturan juga memperjelas penampilan gambaran, baik mengenai tokoh, tempat, suasana, maupun peristiwa. Secara estetik, janturan berfungsi untuk membuat suasana atau kesan tertentu, dan mempertebal kesan dan atau suasana yang telah muncul (simak Mudjanattistomo, 1977: 74; Murtiyoso 2007: 11; Solichin dan Suyanto, 2011: 50-51).

Janturan pada pementasan wayang kulit purwa, terutama pada jejeran pertama, merupakan deskripsi yang panjang, disusun dengan bahasa Jawa rinengga (bahasa yang kenès, bertingkah/puitis). Berkaitan dengan kekenèsan bahasa janturan, Murtiyoso, dkk. (2007: 10-11) mengatakan bahwa janturan memiliki ciri khas ialah: (a) berbentuk prosa liris; (b) memuat kata-kata bahasa Sanskerta dan bahasa Kawi serta kata-kata arkhais; (c) terdapat jalinan harmonis antara suasana dan lagu iringan. Ciri khas ini tentu tidak bisa dilepaskan dengan bahasa unik yang memang hanya dipakai di jagat wayang Jawa yang disebut basa padhalangan. Sebuah bahasa yang merupakan campuran dari bahasa Jawa sehari-hari dengan undha-usuknya (ragam ngoko, krama, bagongan/kedhaton), dan bahasa sastra yang dijalin dari kata-kata kawi dan kata-kata yang menyimpangi bahasa sehari-hari (Soedarsono, 1984: 184; Kolimah, 1997: 7). Karena ciri khas inilah rupa-rupanya yang menyebabkan janturan sangat sulit ditangkap maknanya oleh penonton wayang bahkan saat ini untuk mereka yang sudah disebut dalang maupun mereka yang baru belajar menjadi dalang, termasuk mahasiswa Pedalangan.

Kesulitan mahasiswa Pedalangan dalam memahami janturan diasumsikan pertama karena mereka tidak hanya anak atau cucu dalang, mereka yang lulusan SMKI, tetapi mereka juga lulusan SMU, SMSR, MAN, dan SMM. Yang menyamakan mereka adalah semua berminat belajar wayang. Kedua, mereka hidup di abad 21, suatu zaman yang serba praktis dan pragmatis. Di era ini masyarakat Jawa, terutama di perkotaan atau di daerah perbatasan kota dan desa, hampir tidak berbahasa Jawa lagi dan meninggalkan unggah-ungguh bahasa Jawa dengan segala ragamnya. Bahkan jika dicermati orang Jawa sekarang ini kebanyakan hanya mengenal ragam ngoko dalam bahasa Jawa dan kosa kata Indonesia. Mahasiswa Pedalangan termasuk menjadi bagian di 
dalamnya. Mereka warga masyarakat yang berada dalam situasi memudarnya beberapa tatanan masyarakat Jawa akibat dari dunia yang tanpa sekat ini. Tatanan yang memudar itu termasuk tatanan dalam berbahasa. Sangat mungkin dalam kehidupan mereka sehari-hari sejak lahir, mereka hanya diperkenalkan bahasa Jawa ragam ngoko dan ketika tumbuh menjadi kanak-kanak dan dewasa mereka berbahasa Indonesia dalam berkomunikasi dengan sesama warga masyarakat. Ketika mereka harus masuk sekolah, dari PAUD hingga SMU dan kuliah mereka memakai bahasa pengantar bahasa Indonesia dan juga belajar bahasa Inggris. Akibatnya mereka tidak terbiasa berbahasa Jawa bahkan tidak bisa berbahasa Jawa.

Fenomena yang terjadi di dalam belajar mayang ('mempergelarkan lakon wayang') ini, yaitu di satu sisi mereka harus belajar bahasa pedalangan yang estetik dan di sisi lain mereka tidak menguasai bahasa Jawa, memunculkan pemikiran tentang bagaimana belajar membawakan janturan, yang kata banyak orang bahasa dalam janturan merupakan bahasa yang rumit (sophisticated). Artinya bagaimana bahasa-bahasa janturan dapat dipelajari dengan mudah dan akhirnya dapat dibawakan dengan mudah oleh mereka yang sekarang sedang belajar mayang ('mempergelarkan lakon wayang').

Jika diperhatikan paparan tentang janturan seperti telah dikemukakan di depan dapatlah dikatakan bahwa janturan dengan bahasa puitisnya memiliki susunan atau bangunannya sendiri, atau dengan kata lain memiliki strukturnya sendiri. Oleh karena itu penelitian tentang struktur janturan menjadi sangat penting dilakukan guna memberikan satu langkah mudah bagaimana memahami, menguasai, dan membawakan janturan yang baik dalam pergelaran wayang.

\section{Konsep Tatas}

Untuk dapat menemukan pola struktur janturan, konsep tatas dalam estetika catur versi Soetarno dkk. (2007) digunakan sebagai pijakan analisis dalam penelitian ini. Yang dimaksud catur dalam pakeliran tradisi Surakarta adalah semua wujud bahasa atau wacana yang diucapkan oleh dalang di dalam pakeliran. Selain itu juga berarti semua bentuk ekspresi dalang lewat wacana yang berupa narasi maupun dialog tokoh dalam pakeliran (Murtiyoso, 1981:6). Dengan demikian dapat dikatakan catur pada dasarnya sama dengan apa yang disebut unsur naratif dalam pakeliran tradisi Yogyakarta. Unsur naratif dalam pakeliran Yogyakarta meliputi janturan, kandha, carita, dan pocapan. Yang dimaksud janturan dalam pakeliran Yogyakarta ialah wacana yang diucapkan dalang berupa deskripsi adegan yang sedang berlangsung dibawakan dalam gending yang disirep. Kandha ialah wacana yang diucapkan dalang berupa deskripsi peristiwa yang telah terjadi. Carita ialah wacana yang diucapkan dalang berupa deskripsi peristiwa yang sedang terjadi dan akan terjadi. Pocapan ialah dialog antara tokoh wayang (Mudjanattistomo, 1977: 14).

Tatas artinya narasi (janturan, dan pocapan/ $k a n d h a^{1}$ ) ditampilkan dengan jelas, urut, dan tidak tumpang tindih (Soetarno, 2007: 124). Jelas, urut, dan tidak tumpak tindih yang terkandung dalam konsep tatas menyarankan adanya urutan yang sistematis dari unsur-unsur yang berelasi membentuk satu pengertian. Apa yang disarankan oleh konsep tatas mengarahkan pemahaman pada konsep tentang struktur gramatikal ukara ('kalimat') bahasa Jawa. Ukara (kalimat) adalah wedharing karep ganep saebab ('gagasan tentang suatu hal yang diungkapkan dengan lengkap') (Sasangka, 1989: 102).

\section{Struktur Gramatikal Kalimat Bahasa Jawa}

Ukara dalam bahasa Jawa masuk dalam pembicaraan tentang widyaukara (dalam bahasa Indonesia disebut sintaksis). Widyaukara merupakan bagian paramasastra (tata bahasa Jawa) yang membicarakan kalimat dan juga frasa serta klausa (Sasangka, 1989:94).

Secara gramatikal, sebuah ukara (kalimat) disusun dari bagian-bagian yang disebut jejer (subjek), wasésa (predikat), lésan (objek), katrangan (keterangan), dan geganep (pelengkap). Jejer, wasésa, lésan, katrangan, dan geganep sebenarnya hanyalah kotak-kotak kosong. Oleh karena merupakan kotak-kotak kosong maka harus diisi kata atau

Dalam tradisi pakeliran Yogyakarta pocapan disebut kandha. 
kelompok kata (frasa) (Sasangka 1989: 103-104). Berdasarkan susunan gramatikalnya, Sasangka (1989: 103) mengatakan ada 6 tipe ukara bahasa Jawa ialah:

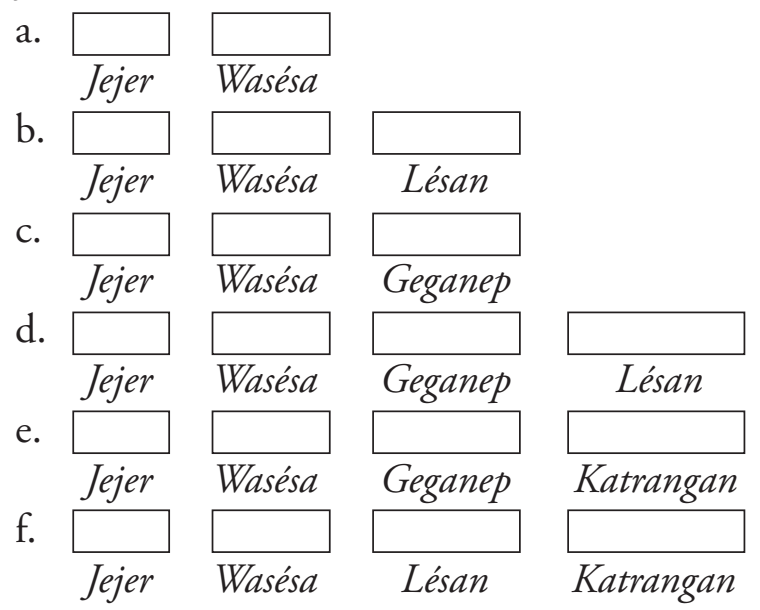

Jejer (subjek) adalah bagian kalimat yang paling pokok. Secara gramatikal, jejer (subjek) terletak di depan wasésa (predikat) (Sasangka, 1989: 105). Wasésa (predikat) adalah bagian kalimat yang menjelaskan (tindakan) jejer (subjek). Wasésa termasuk bagian pokok kalimat setelah jejer. Secara gramatikal wasésa terletak di belakang jejer (Sasangka, 1989: 108). Lésan (objek) adalah bagian kalimat yang menjadi tujuan atau yang dituju. Letak lésan berada di belakang wasésa (Sasangka, 1989: 112). Geganep (pelengkap) ialah kata yang melengkapi tembung kriya (kata kerja) yang mengisi wasésa agar supaya kalimat menjadi lengkap. Geganep (pelengkap) dapat terletak di belakang wasésa (predikat) bisa juga terletak di belakang lésan (objek) (Sasangka, 1989: 115). Katrangan (keterangan) merupakan bagian kalimat yang menerangkan hal-hal yang diutarakan dalam kalimat sehingga menjadi jelas. Katrangan dapat menjelaskan jejer, wasésa, dan lésan. Secara gramatikal, katrangan bisa terletak di bagian depan, tengah, dan belakang kalimat. Sebuah kalimat tidak harus mengandung katrangan. Tanpa katrangan sebuah kalimat telah dapat dipahami maksudnya (Sasangka, 1989: 117).

\section{Konsep Struktur Gramatikal Janturan}

Janturan jika diperhatikan merupakan kalimat-kalimat kenès yang disusun sedemikian rupa sehingga merupakan sebuah deskripsi yang mengungkapkan suatu hal secara lengkap, urut, dan tidak tumpang tindih. Dengan demikian janturan dapat dipandang sebagai sebuah ukara (kalimat). Sebagai sebuah ukara tentu memiliki struktur gramatikal. Untuk dapat menemukan struktur gramatikal janturan yang pada dasarnya adalah sebuah ukara maka di dalam penelitian ini digunakan pisau analisis teori struktur gramatikal kalimat bahasa Jawa yang mengatakan bahwa sebuah ukara minimal terdiri dari unsur: Jejer + Wasésa + Lésan seperti diuraikan di atas. Jejer, wasésa, lésan dalam struktur gramatikal ukara mengisi kotak-kotak kosong. Tentang urutan dari kotak-kotak kosong yang diisi oleh jejer, wasésa, dan lésan, digunakan konsep tatas dalam teori estetika catur yang menonjolkan jelas, urut, dan tidak tumpang tindih. Teori tentang struktur gramatikal ukara dan konsep tatas yang digunakan sebagai pisau analisis dalam penelitian ini secara garis besar dapat dilihat pada gambar 1 .

\section{Identifikasi dan Kategori Janturan Ki Hadi Sugito, Ki Timbul Hadiprayitno, Ki Suparman, dan Mudjanattistomo (Versi Habirandha)}

Untuk dapat menemukan pola stuktur narasi janturan wayang kulit purwa Yogyakarta pertamatama akan dilakukan identifikasi janturan yang dibawakan oleh para dalang senior ialah Ki Hadi Sugito (dalam lakon Bagong Ratu), Ki Timbul Hadiprayitno (dalam lakon Kresna Duta), Ki Suparman (dalam lakon Kresna Kembar), dan Mudjanattistomo (Lakon Alap-alapan Surtikanthi dalam buku Pedalangan Ngayogyakarta jilid 1). Identifikasi janturan dari para dalang senior dimaksudkan sebagai jembatan ditemukannya struktur gramatikal janturan wayang kulit purwa Yogyakarta. Identifikasi ini dimaksudkan untuk melihat pola struktur narasi janturan mereka, yang diasumsikan merupakan janturan yang lengkap karena para dalang senior ini merupakan bagian dari masyarakat yang menghidupi dan menafasi pertunjukan wayang pada zamannya. Selain itu juga dimaksudkan untuk melihat variasi pembawaan janturan dari para dalang senior tersebut yang

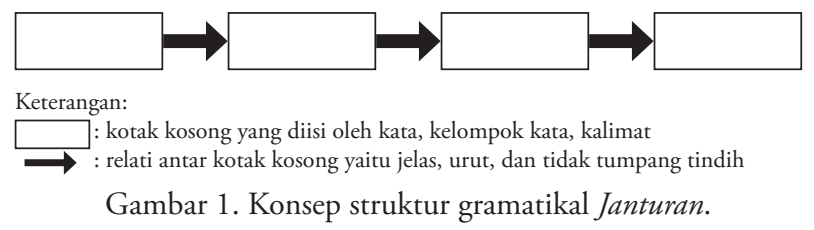


memang tidak diragukan kepopulerannya dan kepionirannya.

Teks dan terjemahan janturan Ki Hadi Sugito (dalam lakon Bagong Ratu), janturan Ki Timbul Hadiprayitno (dalam lakon Kresna Duta), janturan Ki Suparman (dalam lakon Kresna Kembar), dan janturan Mudjanattistomo (Lakon Alap-alapan Surtikanthi dalam buku Pedalangan Ngayogyakarta jilid 1) yang telah disajikan kiranya memberikan gambaran bagian-bagian deskripsi manakah yang dapat dikelompokkan menjadi satu kategori. Identifikasi dan kategori dari janturan yang dibawakan oleh para dalang senior tersebut disajikan dalam bentuk tabel, dengan tujuan agar mudah diikuti dan dipahami. Tabel 1 adalah tabel identifikasi janturan Ki Hadi Sugito, Ki Timbul Hadiprayitno, Ki Suparman, dan Mudjanattistomo (versi Habirandha).

Tabel 1. Tabel identifikasi janturan Ki Hadi Sugito, Ki Timbul Hadiprayitno, Ki Suparman, dan Mudjanattistomo.

\begin{tabular}{l} 
JANTURAN \\
LAKON BAGONG RATU \\
KI HADI SUGITO \\
\hline Hong ilaheng//hong ilaheng \\
awigena mastu purnama \\
sidhem/awigna mastu silat \\
mring Hywang Jagadkaranal \\
siran tandha kawisesaning \\
bisanalsana sinawung \\
langen wilapa estu maksih \\
lestantun lampahing budal \\
jinantur tutur katula \\
tetela tela tulad mrih \\
labdeng paradyalwimursita \\
ngupama prameng \\
niskara gya tumiyeng \\
jaman purwa/pinardi \\
tameng lalata mangkya \\
tekap wusananing gupital \\
manggung pralambang \\
matumpa-tumpalpanggung \\
panggeng panggunggung sang \\
murweng katalhong...
\end{tabular}

Nenggih kang pinurweng gupita ingkang kaeka adi dasa purwalleka marang sawiji adi marang linuwih dasa wilangan sepuluh purwa araning kawitan/ sanadyanta ngupaya praja sewu tanana sadasa satus datan bisa ngaturaken kalib/mung sajuga negara Ngamarta ya negara Ngindraprasthal ya kraton Mretani/ya negara Batanakawarsal yaiku kratone para satriya Pandhawa ingkang kinarya bebukaning cinarita/l kaloka dumugi wonten ing manca negari/yen ta negara Ngamarta panjang apunjung pasir pawukir lob jinawi gemab ripab tata rabarjal/panjang wus ngarani dawa punjung dhuwur upama ta cinengkala sepira ta dawane kraton lan sepira dhuwuring nagari/ora liya kejaba amung dawa kuncarane dhuwur wibawane ya mung dawa jajabane

\section{JANTURAN} LAKON KRESNA DUTA KI TIMBUL HP

JANTURAN

LAKON KRESNA

KEMBAR

KI SUPARMAN
JANTURAN

LAKON ALAP-ALAPAN

SURTIKANTHI versi

MUDJANATTISTOMO DKK

Hong ilaheng/hong ilaheng
awigna mastu purnama
sidham/awigna mastu silat
mring hyang jagad karana
siran tandha kawisesaning
bisana sana sinawung
langen wilapalestu maksih
lestantun lampahing buddal
jinantur tutur katula tetela
mrih labdeng paradyal
winursita prameng niskara
karana dya tumiyeng jaman
purwalwinisudha trah
ingkang dinama damal
pinardi tameng lalata
mangkya tekap wasananing
gupitaltan wun renggeng
pralambang matumpa-
tumpalmarma panggung
panggeng panggunggung sang
murweng katallhong. gong
(slk.kbg)

Anenggih pundi ta kinarya bebuka murciteng kawi samangke ingkang kaeka adi dasa purwalbasa eka tegese siji adi linuwih dasa sepuluh purwa wiwitan/ sanadyan gumelaring jagad marcapada kathah titahing jawata ingkang sinangga ing pratiwi

kasongsonganing akasa kinapiting samodralayal kathah kang sami hanggana raras/pranyata den upaya sewu datan wonten sadasa/sanadyan satus datan jangkep tiga/l Adi-adining garba gupita datan kadi sajuga Nagari ing Ngastinapuralya

Limanbenawi//hong...... (slk.kbg) (kn-1) Pramila Nagari Ngastina kinarya bebuka murciteng kawilawit nagari kasebat panjang apunjung pasir wukir lob jinawi gemah ripab karta rabarjalbasa panjang tegese dawa punjung dhuwurl kalamun kacandra sepira ta dawane prajalpranyata
Hong ilaheng, hong ilabeng awigna mastu purnama sidham mastu silat mring Hyang Jagadkarana siran tandha kawisesaning bisanal sana sinawung langening wilapa saestu lestari maksih lampahing buda/jinantur tutur katela tula tulad mrih labdeng paradya winursita parameng niskaralkaranadya tumiyeng jaman purwal winisudha trah ingkang dinama-dama pinardi tameng lalata mangkya tekap wasananing gupitaltan wun renggeng pralambang matumpa-tumpa/manggung panggeng panggunggung sang murweng kata/Ong..

Ana ratu lelata rila sekaring bawana pramuning rat pramudita branta radyal titah kasangga bantala kaungkulan ing akasa anenggih pundi ta waul ingkang kaeka adi dasa purwa madya wusananiral murwani tembung kawi eka sawiji dasa sepuluh hadi linuwih purwa wiwitan madya tengah wusana pungkasanellamun kapadosan satus datan entuk kalih sewu tan wonten sadasa/kathah titahing jawata kasangga pratala kaungkulan ing akasa sarta kathah negari ingkang samya anggana raras/boya kadi negari Ngamartalya praja Batanakawarsa yap raja Cintakapura ingkang kinarya gupitaning pinurwang kawi/Ong...// Negara Ngamarta kinarya purwakaning cinarita nalika semana ujaring pujanggal wenang denucapake panjang apunjung pasir
Hong ilaheng/hong ilaheng awigna mastu purnama sidhem/awigna mastu silat mring hyang jagatkaranal bisana/sana sinawung langen wilapalestu maksih lestantun lampahing buddal jinantur tutur katulal tela-tela tulat mrih labdeng paradya/winursita ngupama prameng niskaralkarana dya tumiyeng jaman purwal winisudha trah ingkang dinama dama/pinardi tameng lalata/mangkya tekap wasananing gupitaltan wun renggeng pralambang atumpa-tumpa/manggung panggeng panggunggung sang murweng katall

Anenggih nagari pundi ta ingkang pinurweng carita samangke/ingkang kaeka adi dasa purwal eka marang sawijiladi linuwih/dasa sapuluh/purwa wiwitan/adi-adining garba gupita datan wonten kadi nagari Ngastina////nagari panjang punjung pasir wukir lob jinawi/basa panjang marang adawal punjung iku luhur/basa pasir ngarepake samodral wukir ngungkurake gunung/basa jinawi toya tumumpang/tulus kang sarwa tinandur murab kang sarwa tinumbas/ agemab saha ripab/basa gemab kathah janma dagang datan kendhat/ elur tan ana pedhotel basa ripab kathab jalma ingkang gegriya aneng nagari/pratandha eca manahe kawula alit/kebo sapi bebek ayam datan wonten kinandhangan/teka aglar munggwing pangonan/ saking harjaning nagari siran tandha kawisesaning
Bagian II: Deskripsi Kerajaan Besar (yang menjadi pusat penceritaan) 
dhuwur kawekasane/pasir pawukir/pasir samodra wukir gunung/tata rakiting praja mengkeraken pegunungan ingkang langkung ageng ngananaken wana saha pasabinan/ ngiringaken benawi tuwin pategalan ngayuuunaken bandaran ingkang langkung agengl/akeh titahing jawata ingkang sinangga marang pertiwi kasongan dening akasa kaapiting samodrall..... kraton .... Wonten kang padha marang kraton Ngamarta patut karya edi-edining bawanall ing ngajeng wus kacarita yen ta negara katingal lob jinawi lob tulus kang sarwa tinandur dadi/ jinawi murab kang sarwa tinuku mapan para kawula dalem alit/prigel anggen samya among tetanen dhasar siti ketumpangan warih/ apa ingkang tinancebaken tuwuh ijo royo-royol/satemah bisa mahanani murah boga klawan sandhang/ dadya tepa tuladhaning para kawula manca nagaril/ werdining gemab lakuning para sodagar layar para nangkodha rinten pantar dalu labet datan wonten kendhate tansah lumintu wusana kraton Ngamarta dumugi manca nagaril ewadene datan wonten para kawula ingkang nampa sapudhendhaning jawatal lestantun rinten kaliyan dalulyen ta kacandra yayah ilining tirta jalantara. . kacandra para kawula ingkang samya mapan wonten ing kukuban negara Ngamartal/ yen ta katona dinulu candrane jejel apipit adu cukit tepung taritis// papan ingkang wiyar katingal rupak awit saking para kawula trep nganti jejel uyel-uyelan/ ewa semana datan wonten kawula ingkang rumangsa kacingkrangan gesang/ mracihnani kalamun to ageng danane ratul/ora ngemungaken para kawula kukuban negara

Indraprastha akeh kawula manca negari/ingkang samya ndherek gesang wonten ing kraton Ngamarta/senadyan ta pambukane katon papa sudra ngulandara/satemah bisa mulya temah jati/jati temah katemahan mulya kaya bisa nandur debog slaka cindhe awoh kencanall ong...

Gesangira katon tata
Nagari ing Ngastina daw pocapane jembar tlatabe lubur kawibawane//Pasir samodra wedhi wukir hargallawit tata rengganing praja mengkeraken samodralaya kinapit harga ageng/hangiringaken pradusunan miwab pategalan angananaken pasabinan saha ngayunaken bandaran ageng//Lob tulus ingkang tinandur dadi jinawi murah ingkang tinumbas/pranyata Nagari Ngastina murah kang samya tinumbas/payu kang samya sinadel/Saged sinebat nagari ingkang murah boga miwah wastrall Agemab saba ripab/basa gemab kathah kawula alit kang samya tumindak among dedagang/pranyata dagang layar nakudha ing manca negari tansab limintir/surya pantaraning ratri datan ana kendhatel mboya wonten ingkang nyipta pringga bayaning marga labet datan ana kasangsayaning marga awit saking gemahing prajal aripab katandha kawula alit kathab ingkang samya cumondhok salebeting kitha ing Nagari ing Ngastina/katitik pasanganing wisma katingal jejel apipit pangrasa adu cukit tepung taritis ngantos papan wiyar katemahan rupak/karta katandha kawula alit ingkang mapan wonten karang pradusunan katingal denya eca manaheltansah nungkul denya among tetanen/sami angulah wulu wedaling siti pasabinan miwah pategalan/sadaya sami nindakaken sabdanira para winasis babagan tetanenlawit kalis saking durjana juti katebihan dening parangmuka karya pratandha ingon-ingon rajakayallan lembu mahesa menda ayam kambangan lan sapanunggalaniraldatan kang samya cinancangan samya tata gelar wonten pangonan/kalamun ratri wangsul dhateng kandangnya sowang - sowang//Raharja sangyaning para kadang sentana sri bupati nayakaning praja myang para wadyabala medhak marang kawula alit datan wonten ingkang sami tumindak cecengilan cengkab rembag lan sapanunggalanira//Surya pantaraning ratri katingal sahiyek saeka kapti/denya pawukir/loh jinawi gemah ripab karta tata tur rabarja/panjang werdine dawa punjung aranira dhuwur/sineksen kawula dalem tiyang alit sumawana narendra manca negara/nata ing Ngamarta sawenebing narendra ingkang dawa kuncarane dhuwur kasinggihanira sarta jembar polatane padhang obore/katitik surya pantara ratri sang nata balaba ing sesami dhemen andadar marga kawulane pangan boga kadang saha kawula ingkang nandhang kaluwen paring obor kadang sarta kawula ingkang nandhang peteng jagade/pasir pawukir/pasir samodra wedhi wukir harga/pranyata lenggabira negara Ngamarta ngajengaken wukir dhedhangkalmengkeraken samodralaya nganan ngiringaken pasabinan ingapit benawi saha mangku bandaran agung/lir samodra tanpa tepi jembar rowaning negari Ngamarta/pramila yen kacandra sakelangkung lob jinawi/lob werdining siti tumumpang warih jinawi tulus ing sarwa tinandur subur sarwa tinancebake murab sarwa tinumbas/katitik tanem tuwuh palawija kapendhem kasimpar gumantung sapanunggalanel rina wengi ketingal ijo royo-royolsanadyan ta wiji datan tinanem kabekta kukila miber/kecer dhawah mungguhing wreksa lan sela thukul angrembaka woh-wohanira gorohing cinarita kawula dalem alit nandur wit pisang thukul kencana salagine pupuse wae mujudake cindhel gemah sarta ripab/gemab lakuning kanca dagang layar nakudha bakul sapanunggalane rina wengi datan ana pedhote labet sangsayane margal ripab mratelakake kathah para kawula dalem tiyang alit ingkang sami suwital dinulu papan jembar katingal rupak jejel puyel apipit adu tritis/nadyan kathah pasuwitane para kawula dalem tiyang alit/suprandenen negari Ngamarta wenang den ucapake karta tata tur rabarjalawit pranyata negari adob lakuning prangmuka adob lakuning kadurjanan/ora ana kawula kang darbe dora cara sirna ajrih

wilalating narendral 
titi tentrem ayom ayem/ rinten pantara dalu tansah lestantun nggennya hamakarti/heng. .

Karta katandha para kawula ingkang remen ngingu rajakaya maesa lembu kambangan ayam kuda menda sapanunggalane/tanana kang cinancangan saha boya ana kang kinandhangan/ yen ta rina samya tata gelar dhateng pangonan/ yen ta wengi temah wonten papanira dhewe-dhewe ketingal nggenira sowingsowangan/ewa semana kalis ing durjana tebih dhateng parangmuka cinaketaken marang karaharjan/kathah para kawula datan wenten kang remen tumindak cecengilan pasulayan atut runtut rukun ngangkat tata katentremaning prajall dhasar negara Ngamarta sato mara sato mati mungsuh mara keplayulawit rikala semana sinebataken kraton kajiman gawat kaliwatliwat/wingit kepati-patil kukila mabur ngungkuli kraton Ngamarta njungkel kapisanan plak kapidara luntak ludira sirna marga layullakuning mega piniyak lakuning barat mangemper senadyanta mandira kang adoh manglung cerak saya tumiyung/kapraban marang dene panguwasaning prajal akeh para raja maharaja tuwin para ratu maharatu yen .......tanpa karana ginebaging pancakara/saben kalamangsane ngaturake pundhutaning ratu penipeni raja peni guru bakal guru dadi/tumraping tata gelar ngaturaken pisungsung menggah ing batos yen ta kalamun kayungyun marang poyaning kautaman//

//Pinunggel semanten rumpakanira nenggih kang pinuju tinangkil wonten ing dhampar kencana iku warnanira nalendra ing Ngamarta yen ta kacarita dasanamanira//heng.../ dasa wilangan sepuluh/nama werdining ... den ucapne ingkang sinuwun jejeluk Prabu Puntadewa ya Prabu Yudhisthira ya Prabu

Darmakusumalya sang Tandha Dwija Kangkal pinuju lenggah wonten ing dhampar kencana lemek kasur babut prangwedani ... karenda cinawi sinawuran ganda wida katyuping samirana/mangambar sami angangkat karyaning prajallAwit saking ageng perbawanira sri narendra dora cara sirna sedaya sami ajrih marang wilalating narendral/hong (slk.kbg) (Gong nem). pakarti cecengilan panastenan milik darbeking liyan/ sanggyaning para kawula dalem tiyang alit/ minggahing para abdi dalem bupati nayaka surya latri ngetingalaken manunggaling karsa sesarengan hangangkat karyaning prajallabet nagari Ngamarta duk rikala semana purwakaning cinarita/satunggaling negari kajiman/pranyata ngantya dumugi jaman samangke ageng perbawane gedhe daya panguwasane/Ong...// Wenang den ucapake gawat keliwat werit wingit sato mara sato mati jalma mara mara keplayu/kinarya pratandha gorohing cinarital kukila miber ngungkuli kraton dhawah kantaka luntak ludira dadi lan sirnaniralbarat nempuh kraton mangèmpèh-èmpèh mendhung ngungkuli byak padha sakalaldayaning kraton semanten mracihnani lamun keparenging jawata ingkeng hakarya jagadl sampun dumugi titi wanci sura dira jayaningrat lebur dening pangastuti saka wilalating narendral
Mboten wonten panjenenganing narendra ing sak jagad pramudita ingkang sinangga ing pratiwi/kasongsongan ing akasalkagebeng ing muharal ingkang kawengku ing samodralayalingkang kasenenan Sang Hyang Candralingkang kepadhangan Sang Hyang Surya/pranyata datan paja mirip kadya wong agung ing Ngastina// Panjenenganing narendra tumindak adil paramarta berbudi bawa leksana tansab ngemong balaba marang sesami dana boga lumintu ing saben dina
Lah sapa ta wau dasanamanira narendra ingkang angrenggani praja ing Ngamartaldasa sapuluh nama jejuluk/jejuluk Prabu

Darmakusumalya Prabu Puntadewa Darmajaka Gunatalikrama ya Prabu Yudhisthira ya Prabu

Darmawangsa/narendra ingkang kondhang kalokaning rat berbudi bawa lekksana sipat adil paramarta dhemen anggeganjar marang kawulane/
Mboten wonten panjenenganing narendra ing rat jagat pramudita ingkang kasongan ing akasa kagebeng ing muaralingkang kawengku ing samodralayal ingkang kasenenan sang hyang candralingkang kasenenan sang hyang candralingkang kapadhangan sang hyang suryaldatan paja mirip kadi wong agung ing Ngastina punika lubur kawisesanira/pranyata wong agung ing Ngastina punika adil paramartal tansah mule balaba ing brana/dana boga lumintu ing saben dina/ngupaya
Bagian III: Deskripsi Raja Agung (di kerajaan besar yang menjadi pusat penceritaan) 
dumugi pagelaran jawi/ yen ta kacarita kaprabon dalem ingkang sinuwun datan wonten sepiraal ngagem makutha kencana jamang sada sakler/pinacak ginelung keling sumping praba ngayun/lkampuh cineplok rinenda cinawil uncal mas ginepeng sinjang semin ginambarlsinautan badhong giwangkara ngagem lancingan cindhe puspita/nganggar pusaka dhuwung kanjeng kyai kopek/deder tinatah tinatur rengga hanunggak semi ... mata pitu lan ganja den aben-aben manis warangka kayu timaha kandelan kumalo tinetes kencana ... marang pajaring rabina pating galebyar pating celorot//mengkeraken para abdi dalem bedhaya srimpi manggung cethi ... jaka palara-laralingkang samya ngampil upacaraning pasowanan banyak dhalang sawunggaling ardawalika lan badhak kendhi kencana kacu mas/ingkang samya ngampil upacaraning pasowanan netepi marang kuwajiban yayah widadar mangejawantah/ awit ngupaya dasih utamil/

memulang wong balilu/ anjangkung prang apupub/ngapura lepating wadyalanggung tiniti priksa lumintir pangreh utamal/Panjenenganing narendra kinacek sasamining ratu/tur padhang paningalélageng obore dhuwur kukusel atebib kumarane/pramila kasusra kalok kajana pria saking liyan praja bilih narendra agung denya kekadang//Kocapa sinten ta dasanamanira sri narpati wauldasa sepuluh nama aran sri ratu narapati wus mastani//Pranyata tiyang agung ing Ngastina wirange den punjeni den kunceni sedanira den dhadhahaken//Yeka jejuluk Prabu Duryudana ya Prabu Jakapitana ya Prabu Kurupati ya Prabu Anggendariputra, ya Prabu Dhesthaputra, ya Prabu Trimamangsah. Mila jejuluk Prabu Duryudana, dur tegese awon yu raharja dana peparing//Naréndra Ngastina ngasta pusaraning praja Ngastina njagi rahayuning para kawula tumindak agung dananirall Amung kuciwanipun datan menggalih lelabetaning para kawula//Katitik ingkang pinaringan ganjaran amung para kadang kulawarganira pribadi//Mila jejuluk

Prabu Jakapitana awi nalika sinengkakaken ing ngalubur jumeneng nata wonten ing nagari Ngastina yekti maksih mudha dereng nambut ing akrama silaning pramada jalu sisaning akramal/Ya ajejuluk Prabu Kurupati/sayekti angratoni dharah kurulya ajejuluk Prabu Anggendari putral dhasar putra kusumaning ayu Dewi Anggendaril/ Ajejuluk Prabu Dhestaputra sayekti putra pembayun Prabu Dhestharastrall Ya ajejuluk Prabu Trimamangsah/tri tetelu setya wacana lila ing brana sura ing pati mamangsah sampun mestani//Narendra Ngastina sayekti putus olah kridhaning aperang datan samar saliring gelaring aperang//Mila jumeneng nata wonten nagari ing Ngastina katingal ageng prebawaniralkatingal sato mara sato mati jalma mara kaplayu//Sanadyan mega piyak barat mangemperemper/bebasan kayu adoh sami tumiyung kang celak dasib utama/memulang wong balilu/njangkung prang pupub/ngapura lepatingwadyalanggung titipariksa/mintir pangreb utama/panjenenganing narendra kinacek sasamining ratu/trus padhang tingale ageng obore atebih kumaranel tinenga-tenga ing parangmuka/kasusra kajana priya yen ratu pinunjul akekadang// Sinten ta dasanamanira sri narapati ing Ngastina punikaldasa sapuluh/nama aran/sri ratu/narapati wus mastani/pranyata wong agung ing Ngastina punika wirange den punjeni

den kunceni/sedane den dhadhahaken/lajejuluk sang prabu Duryudana, ya Prabu Jakapitana, ya Prabu Kurupati, ya Prabu

Dhesthaputra, ya Prabu Gendariputralyang sang

Tri mamangsahl/mila ajejuluk Prabu Duryudana dur awonlyu raharjal dana marang paweweh/ pranyata wong agung ing Ngastina punika lamun anggeganjar datan mawi pilih awon saening wadyal mila ajejuluk Prabu Jakapitana, dene nggyanira jumeneng nerendra maksih awewujang/dereng nambut ing akrama silaning pramadalmila ajejuluk Prabu Dhesthaputral dene putranira Prabu Dhestharastralmila ajejuluk Prabu Gendraiputral pranyata putranira Dewi Gendari/mila ajejuluk sang Tri Mamangsah/tri tetelul setya wacanallila ing branal sura ing pati/mamangsah wus mastanil/kathah para raja ing liyan nagari ingkang sami nungkul datan sarana linawan ing ayudalajrih asih kumawulalsami asrah bulubekti myang glondhong pangareng-areng/guru bakal guru dadi/minter tan ana kendhate lumados ing saben warsall 
sami manglung//kathah

para raja kang samya

tumungkul datan sarana

linawan ing ayuda//Mboten

ngemungaken tlatah nagarill

kathah para narendra kang

samya nyaosaken bulu bekti

myang glondhong pengareng-

areng/saben antara mangsa

tansah lumintir datan ana

kendhate//Sami nyaosaken

pundhutaning ratu peni-peni

raja peni guru bakal guru

dadi sotya miwah widurill

Para narendra manca

negari samya tumungkul

wonten Nagari ing

Ngastina datan sarana

linawan bandayuda//

Pranyata amung

rumaos sami kaluburan

prebawanira sang nata

ing Ngastina// duk rikala lenggah wonten
ing dhampar kencana

ingkang sinuwun kawistara

ning-ning pindha jaladri

neng-neng kadya arga/mulat

pasebane para narapraja

ingkang wonten pagelan

jawi senadyan akeh para

wadyabala datan wonten

sumawana imbal wecana/

yen ta kapiyarsa saking

palenggahan agung/pating

... pating klesik yayah gana pinupitalgana wus ngarani maling ginupita kencana pindha duratmaka ingkang pikantuk kencanal/anenggib ingkang kepareng ngayun/nembe kewala tedhak wonten ing sitinggil binaturana sesepub ing negara Ngamarta pandhita sakaling Pertapan Guwa Kencanal/ingkang kepareng pepearab Resi Wacanadewall senajan taw us pupuk ampas jambu uwanen bebasanel saknyatane Resi Wecanadewa ....rasalmumpuni bontosing kawruyh/winasi pangulahing ngelmu bisa mikut marang para putraputra Pandhawal/kepareng anedhaki ing pepanggihan kraton Ngamarta kadherekaken ingkang putra angkat satriya Jodhipati kaleres kadang mudha marang ingkang sinuwun ya satriya ngajurit pawenang Raden Harya Werkudara yang Raden Bratasenalya Raden Dadunwacana ya Raden Wijasenal/satriya kang wis kaloka pinunjuling apapak mrojol ing akarep/ patut kawisudha minangka bebetenging praja Ngamarta pilih tandhing kalamun to manjing ing ngayuda/Raden Harya Bratasena lenggah jejer marang ingkang
Kapunggel semanten kawibawaning praja tatkala semanten dhumawah mangsa kartika dinunten respati sang nata kepareng ngawontenaken paseban agung//Ingkeng kepareng caket pisowanira tumungkul yayah konjem ing pratiwil pisowanira sang nata nendya mantri muka pangarsa Rekyana Patih Harya Sengkuni ya Raden Trigantalpatil ya Raden Harya Suman/l Patih Harya Sengkuni wong agung Ngastina sanadyan wus ndungkap yuswa wus gempong perot jambul wanen amung kaloka ing jagad kajulikaning manah buntas ing ngelmu pangrehing prajal/Mila

datan mokal pinitados ngasto abang ijoning praja ing Ngastina//Sang rekyana Patih Harya Sengkuni mengkeraken pisowanira Pandhita Sokalima peparap Begawan Durna ya Dahyang Kumbayanal/(slk. kbg) (Gong).

Begawan Durna sanadyan saranduning badan kuciwa amung kaloka/sajuga pandhita ingkang buntas ngelmu lahir trusing batin// Sang tapa Begawan Durna jajar pisowanira nata Ngawangga Prabu Basukarnalya Sang Surya Putral/Prabu Basukarna mengkeraken pisowanira sangyaning para kadang Kurawa sinambet para kadang sentana/mantri bupati nayakaning praja/sumawana para wadyabala hander pisowaning para wadya hambelabar dumugi nalika semana pinuju ri Soma Manis/narendra ngawontenaken pasewakang agung bènèh karo adat saben/yen kacandra pisowaning para kadang/repepeh kadya sata panging krama kepara ngarsa sowanira rayi dalem sakembaran/satriya Sawojajar lan Bumi Retawu kekasib Raden Nakula Bambang Sadewa meger-meger lenggahira pan yayah tugu sinukarta jajar ingkang rayi

panggak/satriya Tunggul

Pawenang kekasih

Harya Werkudaral

ya Harya Bimasena ya

Raden Kusumayudal

Raden Harya Werkudara mengkeraken sowanira mantri pangarsaning praja Ngamarta peparab Rekyana Patib

Andakawana ya Rekyana Patih Sutakawanalrekayana Patih Andakawana mengkeraken sakathabing para abdi dalem/bupati nayaka lurab mantra penewu bekel riya jajar/ andher pisowaniraltiyang abdi dalem kawula tiyang alit saking kathahing kawula ingkang sami sowan yen dinulu mblabar dumugi Pangurakan/kacarita solah sebawaniralilang sipating abathara pan yayah sela blekithi/sela werdining watu blakithi ratuning semut/kaya ratuning semut ngirit wadya balanira rumambating sela ageng milir tanpa ana pedhotellah ing ta wau nalika semana madyaning pendhapa ageng palenggahan dalem dhampar kencana ingkang wus cumawis/sang nata Prabu Puntadewa
Kocapa ingkang sowan ing pagelaran/inggib punika sang rekyana patih arya Sengkuni ingkang pilenggah ing Plasajenar/Pandhita

Durna ing Sokalimal tuwin Narapati Karna ing Ngawangga/kasambetan

para Sata Kurawal wadya bala ingkang sumewa pepak/mangaler dumugi ing Pangurakan/ mangilen dumugi ing wantilan/mangetan dumugi ing Monggangan/ saking kathahing wadya ingkang anangkil/kadya andhoyong-dhoyongna pacak suji kayu arenglambelabar lir samodra tanpa tepil pangangge maneka warnal ingkang saking salakal suwasa kancana lan sesotyal sorote pating karenyep pating palancurlangebeki ing panangkilan/yen sinawang saking mandrawa lir pendah wana karembun mangsall

Kocapa wong agung ing Ngastina karsa miyos siniwakalangrasuk busana kaprabon/ri wusing samektal jajaran ingkang medal rumiyin/prajurit ingkang caos hurmat/tambur slompret munya gumerab/ sanjata ageng munya rambab kaping tigal clorrrrot gur//
Bagian IV: Deskripsi Para Sentana, Punggawa, Prajurit yang hadir di dalam sidang 
rayi/satriya Madukara Raden Janaka ya Raden Danawikara ya Raden Arjuna/ingkang wus kaloka bagus warnane mudha dhasare patut kinarya kembanging kraton Ngamarta kabukti kahe para jawata kang asih marang Raden Janaka wus tautate dadi jagone para dewal/Apadene ingkang rayi kekalih kembar kamanikan Raden Nakula tuwin Raden Sadewa ingkang wus kondhang yen ta baguse padha agemane padhaldatan sisip sarekma pinarasasra nganti akeh para tamu tamu saking manca negarai ingkang samya tambuh ngendi kang mudha ngendi kang wredhalltuhu kinasih marang ingkang sinuwun nata Ngamarta yekti datan ginggang sakrikma pinarasasrall heng.../Itan apisan nindya mantrimuka ngarsa nata dalem ing Ngamarta/rekyana patib Andakawara ingkang tinanggenah atur pasebaning para narapraja abdi dalem nayaka para tumenggung mantra bupati wedana penewu demang lurab bekel sapanunggalane/ sireeep... tan ana kang samya sabawal... waringin boya obah maruta datan lumampah mung swaraning para abdi gemblak gendhing kemasan/rinten pantara dalu samya tumandang damel pating jeregleng pating terengkli/ewa semana bisa amuruhi asrining pasowanan kraton ing Indraprastha/heng. . Paripurna candraning kraton Ngamarta nenggih ingkang wus tinangkil arsa medhar sabda ingkang kinarya tandhane songsong siningkap minggah sitinggil binaturetna/minangka tandha tengara yen ta wong agung sumedya medhar sabdalsagunging para wadyabala ingkang wonten pasowanan jawi tanggap sasmita sigra ngangseg nggennya samya marak sowan horek ing paseban yayah gabah den interil ndhesuk ringin gunung pinacak sucilyen ta kacandra kaya negara kalebon parangmuka sumyak gumuruh swaraning para wadyabala ngangseg/he kanca ngangseg kanca ndadari kanca ndhodhok kanca maju maju sak sak clorooot...// pangurakan/mangilen dumugi ing wantilan/ mangetan dumungi ing monggangan//Kadya andhoyong-dhoyongna pacak suji kayu areng/l

Samya mangagem busana ingkang maneka warnal tinon saking mandrawa pindha panjrahing puspitall Ingkang samya ngagem busana saking salakal suwasa kencana lan sesotya kasorotan Sang Hyang Bagaskara katingal pating galebyar pating paluncar yayah praba binabarll

Nalika semana horeg pisowaning para wadya balalingkang hamurwani horeg pisowaning para wadya awit wonten rawuhnya pepundhen para kadang Kurawal Pandhita ing Talkandha Sang Resi Warabisma ya Begawan Dewabratall Rawuh wonten ing nagari Ngastina sinarengan nata Mandaraka Prabu Salyantaka//Rawubnya pepundhen kekalih sigra den ingacaran lenggahl kepareng palenggahanira jajar sang nata ing ngastinal Nalika semanten bawane sang hyang bagaskara wus mangrangsang ing akasal sang nata kepareng sedya lenggah siniwaka langkung rumiyin angrasuk busana kapraboning narendral ngagem makutha kencana binuka wekasan jamangmas sungsun tiga kinancingan garudha mungkur/utahutahan pinara wista dhumawah ing wuntat sinangga praba kencanall Renda cinawi kang pinangka tetali//Ngagem sumping gubahan sureng pati uncen tiba jajall Anting manik sotyaning warib//Ngagem ulur-ulur naga mangsa gelang kelat bau salira pindha sarpa

binggelan ataswara sinangga calumpringan//Ngagem sumpit tanjung sakembaran/ ngagem clana cindhe puspita gubeg pinalipit renda cinawi pinathik nawa retnall Ngagem dodot semen paningset cindhe wilis/uncal mas ginepeng sakembaran dhumawah kanan miwah kering//Bebadhong giwangkara tinaretes inten barleyan//Ngagem wangkingan warangka ladrang/sarungan kang kinarya wreksa cendhana murni kang kasinungan pelet dheket dedringin/l sira ngrasuk keprabon dalem/pra pantara lama paripurna pangapiting keprabon dalem/agem dalem busana kesorotan Ywang Pratanggapatil pating glebyar pating calorot ora mantra-mantra Prabu Darmakusuma lenggah dhampar kencana lamun sinawang saking mandrawa pan yayah jawata ngejawantahl paripurna pangrasuking keprabon sigra mijil saking jroning kraton dungkap titi wanci sang nata miyos siniwakalya Prabu Puntadewa kahayap sakathahing para abdi dalem emban manggung cethi biyada srimpi bedhaya jaka palara-laral ingkang samya ngampil klangenan dalem banyak dhalang sawung galing

bardawalika lar badhak kencana kendhi mas/sarta kahayapaken sakathabing dalem bocah bajang bocab bule cebol penong sapiturutira/kacarita abdi dalem niti guna tengara sigra natap bendhe kanjeng kyai Dudha caos atur pakurmatan/abdi dalem pengrawit Warga Laras natap gangsa

kanjeng kyai Sekar Madu sinarengan jumegluring mriyem tambur kalantaka mangambal-ambal para kawula dalem tiyang alit ngarsa tandha pakurmatan sigra ngangseg sowaniral mangkono cipta panegar swarane kanca ndhodhok kanca njajari maju ngangseg maju maju sak sek sak sek o... 
Endah Budiarti, Struktur Janturan Wayang Kulit Purwa

Kandelan tinatah tinatu rengga dedeg nunggak semi ganja den aben-aben manis/mendhak kaparingan netra mutyara tinon saking mandrawa gumebyar pindha netra kitiran//Ginarebeg sangyaning para abdi manggung cethil bocah para gusti/bocah para jaka palara-lara manggung ketanggung kang samya ngampil upacara kapraboning narendra//Banyak dhalang sawunggaling hardawalika/laring manyura kang mungweng kanan miwab kering// Kacu mas bokor kencanal dwi pangga kang sarwa retnal/Awit saking edi rengganing busana para abdi kang anggarebeg sang nata tinon saking mandrawa pating galebyar pating paluncar pindha wana karembun mangsal/Nadyan ta sang nata katingal mawa teja sumunar hanelahi sumundhuling ngawiyat sirna titahing ngabathara pindha Bathara Kuwera dewaning bandha donya kang mangeja wantahl/ (Gong)

Palenggahan dalem sang nata wus sumadya dhampar kencana paring lemek kasur babut prangwedanil phinalipit renda cinawil pinathik nawa retna sinebaran sari-sari kaparingan ganda pura pinaringan lisah jebat kasturi/hermawar ganda wida kinebutan laring manyura kongas gandanira dumugi ing paseban njawi/ndadosaken cingak sangyaning para wadya kang samya mara sowan/l Riwusing samekta jajaran ingkang mekdal langkung rumiyin/tambur slomprèt munya mawuraban/ senjata ageng ambal kaping tigang dasa tiga gurnat gurnanda mriyem kalantaka munya ambalambalan/horeg swaraning para wadya kadya gabah dèn interi/he kanca dhodhokl para kanca dhodhokl dhodhok/dhodhok/dhodhok jalek/jalek/jalek/jalek/ jalek/songsong gelap katon gumebyar cloroot glur (gt) (00.59)

(Iringan beralih ke gending ladrang) ( $m l)(n t)$. (slk.kbg) 
Struktur (Gramatikal) Janturan Ki Suparman, Ki Hadi Sugito, Ki Timbul Hadiprayitno, dan Mudjanattistomo (Versi Habirandha)

Dari penyajian teks dan terjemahan, kemudian pengidentifikasian dan pengkategorian janturan Ki Hadi Sugito (dalam lakon Bagong Ratu), janturan Ki Timbul Hadiprayitno (dalam lakon Kresna Duta), janturan Ki Suparman (dalam lakon Kresna Kembar), dan janturan Mudjanattistomo (Lakon Alap-alapan Surtikanthi dalam buku Pedalangan Ngayogyakarta jilid 1), kiranya dapat dikatakan janturan yang dibawakan disusun dalam empat bagian yang dideskripsikan secara urut dan tidak tumpang tindih. Berdasarkan tabel identifikasi keempat bagian itu dapat dilihat dalam tabel 2 .

Marilah kita bicarakan satu demi satu dan bagian demi bagian dari janturan yang dibawakan oleh keempat dalang senior Yogyakarta tersebut. Jika diperhatikan bagian pertama yang dalam penelitian ini disebut sebagai Deskripsi Doa Pembukaan dari para dalang senior tersebut sama urutan dan susunan kalimatnya. Hal ini kiranya berkaitan dengan sebutan yang diberikan oleh masyarakat Pedalangan Yogyakarta untuk bagian pertama ini. Mereka biasa menyebut bagian pertama ini dengan sebutan mantram. Sebagai sebuah mantram tentu kata dan urutan kata itu tidak boleh lebih, tidak boleh kurang, dan urutannya tidak boleh dibalik. Rupa-rupanya keempat dalang ini tahu betul apa arti mantram sehingga mereka begitu setia tidak mengadakan perubahan dalam bagian ini.

Sekarang kita perhatikan bagian kedua yang dalam penelitian ini disebut Deskripsi Kerajaan Besar (yang menjadi pusat penceritaan). Pada bagian dua ini diceritakan tentang sebuah kerajaan besar yang termasyhur memiliki banyak negara vassal (kaéka adi dasa purwa), sebuah negeri yang letaknya sangat strategis (panjang punjung pasir wukir), tanah pertaniannya sangat subur, murah pangan dan sandang (loh jinawi), menjadi pusat perdagangan dan pelayaran, sebagai pusat perekonomian masyarakat dalam negeri dan luar negeri (gemar ripah), keadaan negaranya aman, tentram dan damai (karta raharja). Dengan gaya penarasiannya masing-masing, keempat janturan yang diteliti semuanya menceritakan hal tersebut. Ki Hadi Sugito dan Ki Timbul Hadiprayitno, dengan sangat piawai menjelaskan idiom-idiom dengan narasi yang panjang dan detil. Sedang Ki Suparman cukup dengan narasi yang singkat dan cukup sederhana dalam menjelaskan idiom-idiom tersebut. Mudjanattistomo dkk. (buku Pedalangan Ngayogyakarta jilid I) menarasikan janturan dengan lebih singkat dari pada Ki Suparman, namun tidak mengurangi isi deksripsi pada bagian tersebut. Bagaimana idiom kaéka adi dasa purwa panjang punjung pasir wukir loh jinawi dijadikan kata kunci dalam setiap penarasian oleh para dalang tersebut, dapat dilihat dalam tabel identifikasi. Kata-kata yang dicetak tebal dalam tabel identifikasi merupakan kata kunci yang dimaksud.

Pada bagian tiga yang dalam penelitian ini disebut Deskripsi Raja Agung (di kerajaan besar yang menjadi pusat penceritaan) jika diperhatikan dari masing-masing narasi dalang ada sedikit variasi. Ki Hadi Sugito dalam bagian ini hanya menyebutkan raja yang hendak memimpin sidang dan mendeskripsikan pakaian kebesarannya raja yang dalam hal ini beliau membaca ikonografi dari wayang (baca: tokoh raja agung) yang ada di kelir. Sedang Ki Timbul Hadiprayitno di bagian tiga ini memberikan narasi yang detil tentang kebesaran raja: pemimpin yang adil dan bijaksana (naréndra tumindak adil paramarta bèrbudi bawa leksana, tansah ngemong, balaba marang sesami); seorang yang cerdas dalam ilmu kenegaraan dan pemerintahan (memulangwong balilu, anjangkung prang apupuh, ngapura lepating wadya, anggung tiniti priksa, lumintir pangrèh utama, padhang paningalé, ageng oboré dhuwur kukusé, atebih kumarané); seorang yang pandai berdiplomatik

Tabel 2. Empat bagian janturan.

\begin{tabular}{llll}
\hline \multicolumn{1}{c}{ Bagian I } & \multicolumn{1}{c}{ Bagian II } & \multicolumn{1}{c}{ Bagian III } & \multicolumn{1}{c}{ Bagian IV } \\
\hline $\begin{array}{l}\text { Deskripsi doa } \\
\text { pembukaan. }\end{array}$ & $\begin{array}{l}\text { Deskripsi kerajaan } \\
\text { besar (yang menjadi } \\
\text { pusat penceritaan). }\end{array}$ & $\begin{array}{l}\text { Deskripsi Raja Agung } \\
\text { (di kerajaan besar } \\
\text { yang menjadi pusat } \\
\text { penceritaan) }\end{array}$ & $\begin{array}{l}\text { Deskripsi para sentana, } \\
\text { punggawa, prajurit } \\
\text { yang hadir di dalam } \\
\text { sidang. }\end{array}$ \\
\hline
\end{tabular}


dan menjalin hubungan bilateral (pramila kasusra kalok kajana pria saking liyan praja bilih naréndra agung dénya kekadang). Ki Suparman dalam bagian ini pada dasarnya memberikan narasi yang sama dengan Ki Timbul Hadiprayitno, namun lebih singkat. Tentang kebesaran raja ia hanya mengatakan sang raja adalah seorang yang terkenal adil dan bijaksana (naréndra ingkang kondhang kalokaning rat bèrbudi bawa leksana sipat adil paramarta dhemen anggeganjar marang kawulané). Penarasian Mudjanattistomo dkk. di bagian tiga ini dapat dikatakan hampir sama dengan $\mathrm{Ki}$ Timbul Hadiprayitno. Mereka menarasikan raja besar sebagai seorang pemimpin yang adil dan bijaksana (wong agung ing Ngastina punika lubur kawisésanira, adilparamarta, tansah mulébalaba ing brana, dana boga lumintu ing saben dina, ngupaya dasih utama); seorang yang cerdas dalam ilmu kenegaraan dan pemerintahan (memulang wong balilu, njangkung prang pupuh, ngapura lepating wadya, anggung titipariksa, mintir pangrèh utama, panjenenganing naréndra kinacèk sasamining ratu, trus padhang tingalé ageng oboré atebih kumarané); seorang yang pandai berdiplomatik dan menjalin hubungan bilateral (tinenga-tenga ing parangmukal kasusra kajana priya yèn ratu pinunjul akekadang).

Memperhatikan bagian keempat yang dalam penelitian ini disebut Deskripsi Para Sentana, Punggawa, Prajurit yang hadir di dalam sidang dari para dalang senior Yogyakarta dapat dikatakan ada variasi penarasiannya. Dalam bagian ini Ki Hadi Sugito mendeskripsikan para sentana, punggawa, dan prajurit telah berada di ruang sidang siap mendengarkan sabda sang raja. Sementara itu sang raja telah duduk di singgasananya (duk rikala lenggah wonten ing dhampar kencana ingkang sinuwun kawistara ning-ning pindha jaladri nengneng kadya arga). Hal ini berbeda dengan $\mathrm{Ki}$ Timbul Hadiprayitno dan Ki Suparman. Mereka berdua mendeskripsikan para sentana, punggawa, dan prajurit yang ada di ruang sidang sedang menunggu kehadiran sang Raja, yang waktu itu sedang bersiap-siap mengenakan pakaian kebesaran raja dan hendak menuju ruang sidang dengan diiringkan oleh para abdi yang membawa simbol-simbol kebesaran kerajaan. Berikut narasi Ki Timbul Hadiprayitno tentang raja yang bersiapsiap menuju ruang sidang: sang nata kepareng sedya lenggah siniwaka langkung rumiyin angrasuk busana kapraboning naréndra,... Ginarebeg sanggyaning para abdi manggung cèthi, bocah para gusti, bocah para jaka palara-lara manggung ketanggung kang samya ngampil upacara kapraboning naréndra, banyak dhalang sawunggaling hardawalika, laring manyura kang munggwèng kanan miwah kéring, kacu mas bokor kencana, dwi pangga kang sarwa retna).

Sedang Ki Suparman menarasikan raja yang bersiap-siap menuju ruang sidang sebagai berikut: paripurna pangrasuking keprabon sigra mijil saking jroning kraton dungkap titi wanci sang nata miyos siniwaka ... kahayap sakathahing para abdi dalem emban manggung cèthi biyada srimpi bedhaya jaka palara-lara, ingkang samya ngampil klangenan dalem banyak dhalang sawung galing hardawalika lar badhak kencana kendhi mas, sarta kahayapaken sakathahing dalem bocah bajang bocah bulé cébol penong sapiturutira)).

Tiga dalang ini mendeskripsikan tokoh-tokoh wayang yang ada di kelir pada jejer pertama lakon wayang yang sedang dipergelarkan sesuai dengan urutan tanceban tokoh di atas debog. Pendeskripsian ini telah ada tata urutannya (udanegarané) yaitu yang pertama menyebut tokoh wayang yang paling tua dan dihormati, kemudian para kadang sentana, lalu patih dan para punggawa serta prajurit bawahannya, lalu tamu yang hadir. Berbeda lagi dengan Mudjanattistomo, ia mendeskripsikan bagian ini dengan sangat singkat langsung menyebutkan para tokoh wayang yang hadir di ruang sidang.

Setelah menyebutkan tokoh-tokoh wayang yang hadir dalam sidang, kemudian dalang mendeskripsikan hendak dimulainya sidang. Karena Ki Hadi Sugito mendeskripsikan bahwa raja dan para kadang sentana, punggawa kerajaan, dan para prajurit telah berada di ruang sidang maka deskripsinya langsung pada sang nata yang hendak bersabda (arsa medhar sabda ingkang kinarya tandhané songsong siningkap minggah sitinggil binaturetna). Sedang Ki Timbul Hadiprayitno, Ki Suparman, dan Mudjanattistomo mendeskripsikan sang raja yang berjalan hendak ke ruang sidang diiringi para abdi yang membawa simbol kebesaran prajurit dan prajurit yang memberi aba-aba. Untuk lebih jelasnya simak tabel identifikasi bagian keempat. Kata-kata yang dicetak tebal merupakan kata kunci yang menunjukkan hal tersebut. 
Demikianlah pelacakan bagian-bagian dari struktur janturan para dalang senior Yogyakarta. Meskipun ada variasi dalam menarasikan setiap pendeskripsian bagian demi bagian, namun isi pendeskripsian itu dapat dikatakan sama.

\section{Struktur Gramatikal Janturan Wayang Kulit Purwa Yogyakarta}

Seperti telah dikemukakan pada pembicaraan di depan bahwa struktur gramatikal janturan wayang kulit purwa Yogyakarta yang akan dikemukakan merupakan reduksi dari hasil pelacakan terhadap janturan yang dibawakan oleh para dalang senior Yogyakarta ialah Ki Hadi Sugito, Ki Timbul Hadiprayitno, Ki Suparman, dan Mudjanattistomo (versi Habirandha). Karena struktur janturan ini dimaksudkan sebagai satu metode memahami janturan bagi mahasiswa Pedalangan khususnya, atau siapa saja yang hendak belajar mayang namun memiliki kemampuan bahasa Jawa dan bahasa Pedalangan yang terbatas, maka di sini akan diberi sedikit penjelasan dan kata-kata kunci pendeskripsian dari masing-masing bagian dalam struktur janturan tersebut.

Dari hasil pelacakan terhadap struktur (gramatikal) janturan para dalang senior Yogyakarta seperti telah dipaparkan di depan, diperoleh pola seperti tampak dalam tabel 3 .

Bagian pertama merupakan satu bagian yang berisi tentang doa pemujaan. Rupa-rupanya kandungan isi bagian pertama dari janturan gaya Yogyakarta yang demikian itulah menyebabkan masyarakat Pedalangan biasa menyebutnya mantram. Bagian pertama ini dapat disejajarnya dengan bait-bait pembukaan atau manggala sebuah kakawin (puisi Jawa kuna). Manggala ${ }^{2}$ kakawin ialah segala sesuatu, setiap kata, perbuatan atau orang yang karena kesaktiannya dapat menjamin sukses sebuah pekerjaan yang akan dimulai (Zoetmulder, 1985: 203). Di bagian pertama ini jelas Ong Ilahèng, Sang Hyang Jagatkarana, Yang Maha Kuasa, disebut untuk memberkati sang murwèng kata (tukang cerita: dalang) dalam menggelar ceritanya, sinawung langen wilapa. Oleh karena itu kiranya tidaklah terlalu gegabah jika bagian pertama dari janturan ini disebut sebagai doa pembukaan.

Pada bagian pertama ini yang biasa disebut mantram oleh masyarakat pedalangan Yogyakarta, mau tidak mau sang dalang harus menghapalnya dengan setia. Karena mantram itu tidak boleh dikurangi, ditambahi, atau diubah. Hal ini sejalan dengan apa yang dikatakan oleh Pradipta (2003:17) bahwa mantra ialah rumusan kata-kata yang diformat dalam bentuk tertentu, dengan tujuan tertentu, dan dibuat oleh orang yang telah memiliki kualifikasi tertentu pula. Berkaitan dengan kata Hong diawal bagian pertama ini, Walker (1983:26 via Setyawati, 2003:29) mengatakan bahwa bijamantra (mantra satu suku kata dan berakhir dengan anusvara) yang paling berkekuatan adalah Om, kiranya semakin memperkuat kedudukan bagian pertama ini sebagai mantra.

Bagian kedua dari janturan berisi tentang kebesaran kerajaan yang menjadi pusat penceritaan. Oleh karena itu di dalam bagian ini ciri-ciri kerajaan besar dilukiskan sedemikian rupa, seperti negara yang luas wilayah kekuasaannya (ingkang kaéka adi dasa purwa); letaknya yang strategis (nagari panjang punjung pasir wukir); tanah yang subur dan iklimnya yang cocok untuk pertanian (loh jinawi); rakyatnya yang makmur sejahtera (gemah ripah karta raharja). Dikatakan oleh Wahyudi (2014: 6061) bahwa kerajaan yang disebut di dalam janturan merupakan negara yang paling besar dalam sebuah lakon bukan negara vassal. Dengan mengacu pada pernyataan tersebut maka tidaklah terlalu tergesa-

Tabel 3. Pola/struktur gramatikal janturan Yogyakarta.

\begin{tabular}{llll}
\hline \multicolumn{1}{c}{ I } & \multicolumn{1}{c}{ II } & \multicolumn{1}{c}{ III } & \multicolumn{1}{c}{ IV } \\
\hline $\begin{array}{l}\text { Deskripsi doa } \\
\text { pembukaan. }\end{array}$ & $\begin{array}{l}\text { Deskripsi kerajaan } \\
\text { besar (yang menjadi } \\
\text { pusat penceritaan). }\end{array}$ & $\begin{array}{l}\text { Deskripsi Raja Agung } \\
\text { (di kerajaan besar } \\
\text { yang menjadi pusat } \\
\text { penceritaan) }\end{array}$ & $\begin{array}{l}\text { Deskripsi para sentana, } \\
\text { punggawa, prajurit } \\
\text { yang hadir di dalam } \\
\text { sidang. }\end{array}$ \\
\hline
\end{tabular}

Wiryamartana (1990: 348) menyebut Manggala ini dengan Aśir sesuai dengan sebutan doa pembukaan kakawin dalam estetika karya. 
gesa jika bagian kedua dari janturan ini dikatakan sebagai deskripsi tentang kebesaran kerajaan.

Untuk bagian kedua ini seorang dalang selain mengingat bahwa bagian ini disebut deskripsi kerajaan besar yang menjadi pusat penceritaan, dia juga harus ingat kata-kata kunci untuk dapat menarasikan bagian ini. Adapun kata-kata kunci tersebut antara lain: (1) Kaéka adi dasa purwa, (2) Panjang punjung, (3) Pasir wukir, (4) Loh jinawi, (5) Gemah ripah, (6) Karta raharja

Bagian ketiga dari janturan berisi tentang raja agung di kerajaan besar yang menjadi pusat penceritaan. Bagian ini erat hubungannya dengan bagian dua. Seperti halnya lukisan kerajaan besar yang ideal, dalam bagian ini ciri-ciri raja yang ideal juga dilukiskan. Sang raja dilukiskan sebagai pemimpin yang adil dan bijaksana; seorang yang cerdas dalam ilmu kenegaraan dan pemerintahan; seorang yang pandai berdiplomatik dan pandai menjalin hubungan bilateral.

Kata-kata kunci yang harus diingat oleh seorang dalang untuk bagian ketiga ini antara lain: (1) dasanama (nama, sebutan, dan gelar) sang raja; (2) naréndra ingkang kondhang kalokaning rat bèrbudi bawa leksana sipat adil paramarta dhemen anggeganjar marang kawulané.

Bagian keempat dari janturan berisi tentang persiapan sidang dan yang hadir di dalam sidang. Dalam bagian ini intinya adalah lukisan tentang kadang sentana, punggawa kerajaan, dan prajurit yang hadir di dalam sidang. Pendeskripsian ini akan lebih mudah dilakukan dan diingat jika sang dalang memperhatikan tokoh-tokoh wayang yang ada di kelir pada jejer pertama lakon wayang yang sedang dipergelarkan sesuai dengan urutan tanceban tokoh di atas debog. Dengan demikian seorang dalang tinggal melukiskan siapa saja yang hadir di dalam persidangan diurutkan dari tokoh wayang yang paling tua dan dihormati, kemudian para kadang sentana, lalu patih dan para punggawa serta prajurit bawahannya, lalu tamu yang hadir. Setelah menyebutkan tokoh-tokoh wayang yang hadir dalam sidang, kemudian dalang mendeskripsikan sang raja yang berjalan hendak ke ruang sidang diiringi para abdi yang membawa symbol kebesaran prajurit dan prajurit yang memberi aba-aba.

Kata-kata kunci yang harus diingat oleh seorang dalang untuk bagian ketiga ini antara lain: (1) Kocapa ingkang sowan ing pagelaran inggih punika... (2) kasambetan para... (3) wadya bala ingkang suméwa pepak jajaran ingkang medal rumiyin prajurit ingkang caos hurmat.

\section{Penutup}

Ada dua hal yang dapat dikemukakan dari hasil pelacakan struktur janturan wayang kulit purwa Yogyakarta. Pertama, janturan jika diperhatikan merupakan kalimat-kalimat kenès yang disusun sedemikian rupa sehingga merupakan sebuah deskripsi yang mengungkapkan suatu hal secara lengkap. Dengan demikian janturan dapat dipandang sebagai sebuah ukara (kalimat). Sebagai sebuah ukara tentu memiliki struktur gramatikal. Secara gramatikal, sebuah ukara (kalimat) disusun dari bagian-bagian yang disebut jejer (subjek), wasésa (predikat), lésan (objek), katrangan (keterangan), dan geganep (pelengkap). Jejer, wasésa, lésan, katrangan, dan geganep sebenarnya hanyalah kotakkotak kosong. Oleh karena merupakan kotak-kotak kosong maka harus diisi kata atau kelompok kata (frasa). Dengan berpijak pada pengertian struktur gramatikal ukara tersebut maka kita dapat mengatakan bahwa secara gramatikal janturan memiliki bagian-bagian yang berelasi secara berurutan dan tidak tumpang tindih. Bagian-bagian janturan yang merupakan kotak-kotak kosong ini harus diisi deskripsi-deskripsi yang sudah tertentu urutannya.

Kedua, dari hasil pelacakan terhadap struktur (gramatikal) janturan para dalang senior Yogyakarta seperti telah dipaparkan di depan, diperoleh pola seperti dapat dilihat dalam tabel 4 .

Tabel 4. Struktur gramatikal janturan wayang kulit purwa Yogyakarta.

\begin{tabular}{llll}
\hline \multicolumn{1}{c}{ I } & \multicolumn{1}{c}{ II } & \multicolumn{1}{c}{ III } & \multicolumn{1}{c}{ IV } \\
\hline $\begin{array}{l}\text { Deskripsi doa } \\
\text { pembukaan. }\end{array}$ & $\begin{array}{l}\text { Deskripsi kerajaan } \\
\text { besar (yang menjadi } \\
\text { pusat penceritaan). }\end{array}$ & $\begin{array}{l}\text { Deskripsi Raja Agung } \\
\text { (di kerajaan besar } \\
\text { yang menjadi pusat } \\
\text { penceritaan) }\end{array}$ & $\begin{array}{l}\text { Deskripsi para sentana, } \\
\text { punggawa, prajurit } \\
\text { yang hadir di dalam } \\
\text { sidang. }\end{array}$ \\
\hline
\end{tabular}


Pemahaman terhadap struktur gramatikal janturan dimaksudkan sebagai langkah awal dalam mempelajari dan memahami janturan.

Penelitian ini belum tuntas. Dikatakan belum tuntas karena penelitian ini baru melihat struktur gramatikal janturan. Masih banyak hal yang harus dikerjakan atau diteliti lebih lanjut. Di antara masalah-masalah yang masih harus dikerjakan misalnya bagaimana mengembangkan kata kuncikata kunci dalam setiap bagian menjadi narasi yang jelas, runtut, dan tidak tumpang tindih. Bagaimana mengharmoniskan antara deskripsi yang serba singkat dengan iringan/instrumen gamelan.

\section{Kepustakaan}

\section{a. Acuan}

Kolimah, Siti. 1997. Ragam Bahasa Jawa dalam Pedalangan Wayang Purwa. Yogyakarta: Makalah.

Mudjanattistomo, dkk. 1977. Pedhalangan Ngayogyakarta, Jilid I. Yogyakarta: Yayasan Habirandha.

Murtiyoso, Bambang. 1981. Pengetahuan Pedalangan. Surakarta: ASKI, Proyek Pengembangan IKI.

Murtiyoso, Bambang, dkk. 2007. Teori Pedalangan: Bunga Rampai Elemen-elemen Dasar Pakeliran. Surakarta: ISI Surakarta dan Percetakan CV. Saka Production.

Pradipta, Budya. 2003. Hakikat dan Manfaat Mantra. Jakarta: Perpustakaan Nasional.

Sasangka, Sry Satriya Tjatur Wisnu. 1989.
Paramasastra Jawa Gagarag Anyar. Surabaya: PT Citra Jaya Murti.

Setyawati, Kartika. 2003. Mantra Pada Naskah Koleksi Merapi Merbabu. Jakarta: Perpustakaan Nasional.

Soedarsono. 1984. Wayang Wong The State Ritual Dance Drama in The Court of Yogyakarta. Yogyakarta: Gadjah Mada University Press.

Soetarno, Sunardi, Sudarsono. 2007. Estetika Pedalangan. Surakarta: ISI Surakarta dan CV. Adji Surakarta.

Solichin dan Suyanto. 2011. Pendidikan Budi Pekerti dalam Pertunjukan Wayang. Jakarta: Yayasan Senawangi.

Wahyudi, Aris. 2014. Sambung Rapet dan Greget Sahut, Sebuah Paradigma Dramaturgi Wayang. Yogyakarta: Bagaskara.

Wiryamartana, I. Kuntara.1990. Arjunawiwaha, Transformasi Teks Jawa Kuna Lewat Tanggapan dan Penciptaan di Lingkungan Sastra Jawa. Yogyakarta: Duta Wacana University Press.

Zoetmulder. 1985. Kalangwan, Sastra Jawa Kuno Selayang Pandang. Jakarta: Penerbit Djambatan.

\section{b. Audio-Visual}

Dahlia Record, 1994. Kresna Duta Ki Timbul Hadiprayitno. Kaset rekaman audio.

Dahlia Record, 1980. Bagong Ratu Ki Hadi Sugito. Kaset rekaman audio.

Ki Suparman. Kresna Kembar. Audio Visual koleksi pribadi. 